INTERNATIONAL

LABOR AND

WORKING-CLASS

\title{
HISTORY
}
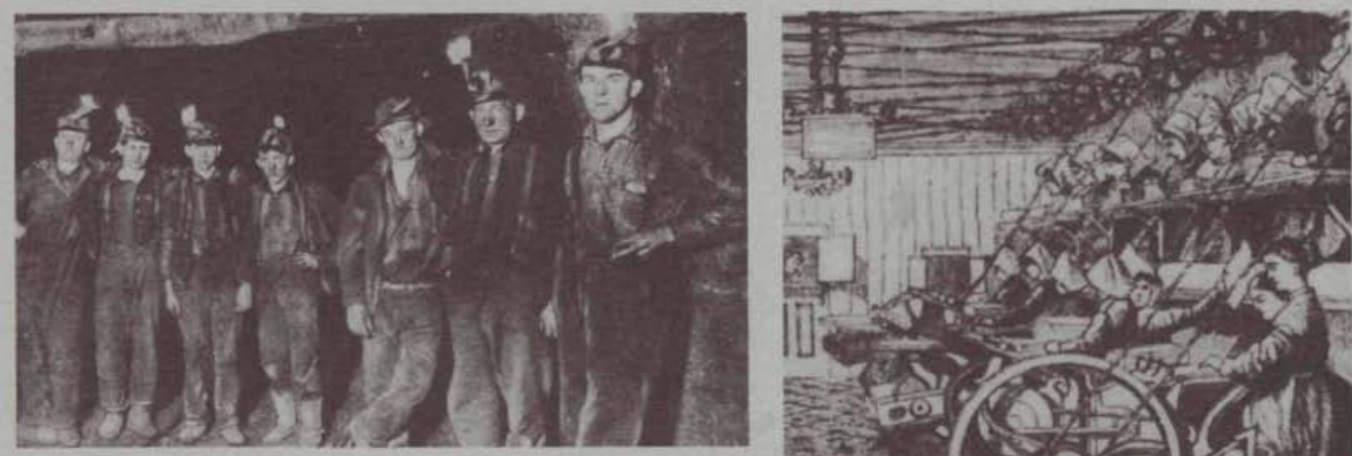

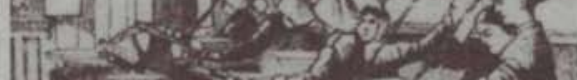
SPRING 1986

NO. 29

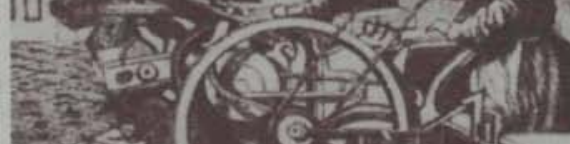

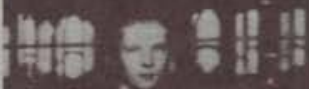

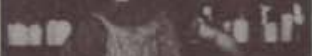

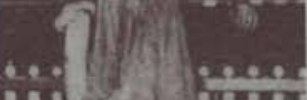

ii)
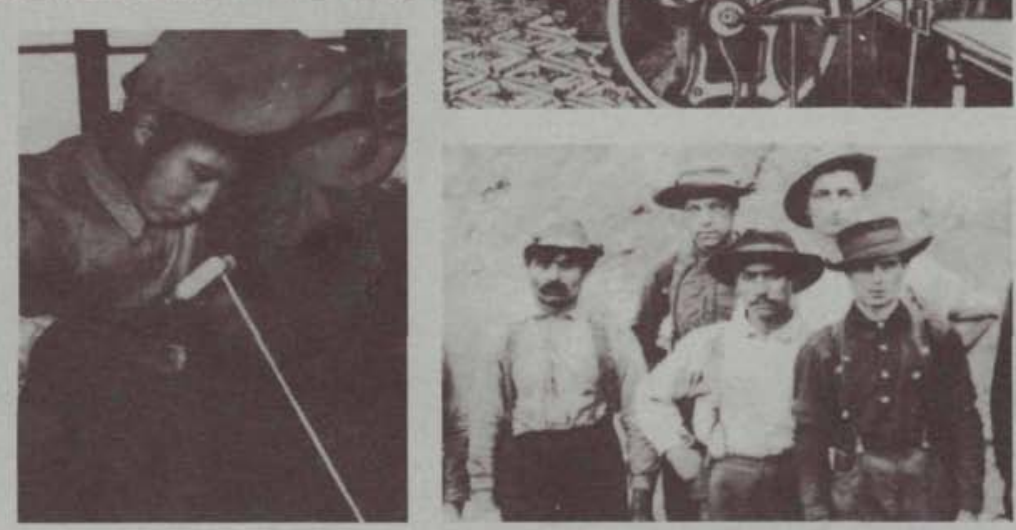

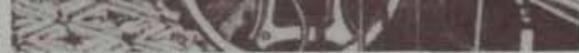

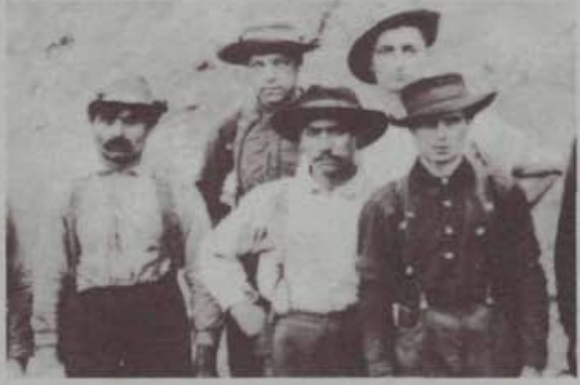

किषे

xhentsis
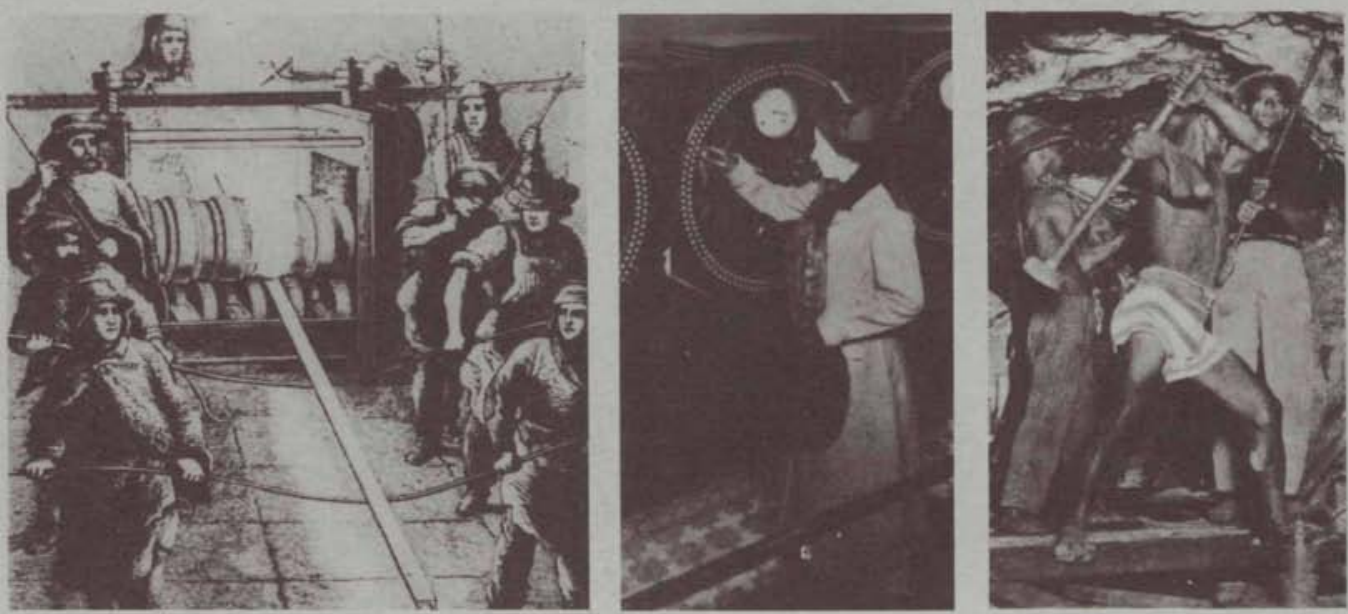


\section{INTERNATIONAL LABOR AND}

WORKING-CLASS HISTORY $\quad \begin{aligned} & \text { Founded by } \\ & \text { Robert F. Wheeler }\end{aligned}$

\section{EDITORS}

David Montgomery Yale University

Helmut Gruber

Polytechnic University

\section{ASSISTANT EDITOR}

Julia Greene

Yale University

\section{EDITORIAL BOARD}

James Cronin University of Wisconsin, Milwaukee

Emilia Viotti daCosta Yale University

John F. C. Harrison University of Sussex

Gregory S. Kealey

Memorial University of Newfoundland

John H. M. Laslett

University of California, Los Angeles

Yves Lequin

Université de Lyon

Vernon Lidtke

The Johns Hopkins University

Martin Miller

Duke University

Nicholas Papayanis

Brooklyn College/CUNY
Anson Rabinbach

The Cooper Union

Steven Ross

University of Southern California

Nick Salvatore

NYSSILR/Cornell University

Michael Schneider

Friedrich-Ebert-Stiftung

Joan Wallach Scott

Institute for Advanced Study, Princeton Louise A. Tilly

The New School for Social Research Joseph Weidenholzer

Johannes Kepler Universität, Linz

Sean Wilentz

Princeton University

International Labor and Working-Class History (ISSN 0147-5479) is published twice yearly, in spring and fall, by the University of Illinois Press for the Study Group on International Labor and Working Class History. Additional support is provided by Yale University.

Subscription rates: $\$ 20.00$ for institutions ( $\$ 26.00$ foreign), $\$ 12.00$ for individuals ( $\$ 18.00$ foreign), and $\$ 7.00$ for students ( $\$ 13.00$ foreign). Single copies $\$ 10.50$. All business inquiries (subscriptions, advertisements, and change of address notices) and requests for back numbers should be addressed to the University of Illinois Press, $54 \mathrm{E}$. Gregory Dr., Champaign, IL 61820.

Manuscripts, editorial correspondence, and books for review should be addressed to Editor, $I L W C H$, Department of History, Hall of Graduate Studies, Yale University, New Haven, CT 06520. Directions for contributors are on the inside back cover of this issue.

(C) 1986 by the Board of Trustees of the University of Illinois.

Manufactured in the United States of America.

This journal is printed on acid-free paper.

All cover photographs are from the Carnegie Library, Pittsburgh, Pennsylvania.

Postmaster: Send change-of-address notices to the University of Illinois Press, $54 \mathrm{E}$. Gregory Dr., Champaign, IL 61820. 
Editor's Remarks $\ldots \ldots \ldots \ldots \ldots \ldots \ldots \ldots \ldots \ldots \ldots \ldots$ iii

\section{THE HAYMARKET}

"We Can't Get Them to Do Aggressive Work": Chicago's Anarchists and the Eight-Hour Movement $\ldots \ldots \ldots \ldots \ldots \ldots \ldots, 1$ Bruce C. Nelson

The Impact of Haymarket on German-American Radicalism 14 Hartmut Keil

And They Sang the "Marseillaise": A Look at the Left French Press

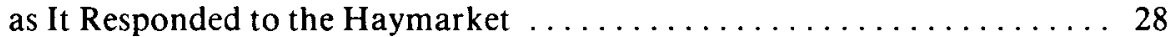
Marjorie Murphy

The "Social Revolution" in America? European Reactions to the "Great Upheaval" and to the Haymarket Affair .............. 38 Hubert Perrier, Catherine Collomp, Michel Cordillot, and Marianne Debouzy

Misguided Martyrdom: German Social Democratic Response to the Haymarket Incident, 1886-87 Raymond C. Sun

Haymarket, Henry George, and the Labor Upsurge in Britain and America during the Late 1880 s 68 J. H. M. Laslett

\section{REVIEW ESSAY}

The French Workers' Movement since 1945 83 Irwin M. Wall

\section{REPORTS AND CORRESPONDENCE}

North American Labor History Conference $\ldots \ldots \ldots \ldots \ldots \ldots \ldots . \ldots 2$ Robert H. Zieger

U.S. Working-Class History and the Contemporary Labor Movement . . . 97 Irwin M. Marcus 
The Sociabilité of Workers and the Working Class in Comparative Perspective ................................... 102 Ellen Ross

\section{BOOK REVIEWS}

Urban Workers and Labor Unions in Chile, 1902-1927, by Peter DeShazo ................................ 109

Reviewed by Dick Parker

Conflict and Accommodation: Coal Miners, Steel Workers, and Socialism, 1890-1920, by Michael Nash

Reviewed by Julia Greene

Dubious Alliance: The Making of Minnesota's DFL Party, by John E. Haynes

Reviewed by Peter Rachleff

The American Law of Slavery, 1810-1860: Considerations of Humanity and Interest, by Mark Tushnet ........................... 118

Reviewed by Amy Dru Stanley

The Remaking of Pittsburgh: Class and Culture in an Industrializing City, 1877-1919, by Francis G. Couvares................... 124

Reviewed by Betsy Blackmar

From the American System to Mass Production, 1800-1932: The Development of Manufacturing Technology in the United States, by David A. Hounshell ...

Reviewed by Eda Kranakis

The Working People of Paris, 1871-1914, by Lenard R. Berlanstein 131

Reviewed by John M. Merriman

NEWS AND ANNOUNCEMENTS .134

CURRENT RESEARCH . 